\title{
Disquiet [of a non-crash site] Non-standard urban encounter
}

Hannah HopeweII

think this: thought is a thing

Fra nçois Laruelle 2012

Disatist ief a non-crash site] forms part of a broader experiment with urban inscription-an experiment played out across photography and philopoetics. As such, the project draws divergently from questions of urbanism, the non-philosophy of François Laruelle, and emerging developments in speculative realism ${ }^{1}$. The practice is offered in three registers, each building on the same 2014 dusk encounter with an inter-tidal space at Juhu Beach, Mumbai, India: firstly, in photographic imagery; secondly, as philo-poetic - or what can be thought of as an intersecting of philosophy and fiction that affords a radicalising of experience ${ }^{2}$; and thirdly, as a brief discursive outline of the project's motivations and non-standard method. Part explication, part performance, this project folds theory and practice in a non-binary mode Gilles Deleuze (1992) has termed expressionism. François Laruelle has invited a similar reworking of the theory/practice nexus: the aim, he writes, is to put "practice into theory rather than just inserting practice "in theory"' (Laruelle 2012c: 218). In this case, I have sought to think an encounter with Juhu Beach intertidal as if the thought itself were a thing, a thing to be observed and inquired into. In this regard the project stakes itself less on questions and materials emerging from the actual site-specificities of the Juhu beach intertidal, and more on the agency of thing-ness in thought. What follows unpacks Disquiet's urban encounter in reference to what Laruelle names as non-philosophy or non-standard method - a style of thought practise and performance pronounced by Ian James as a persistently heretical endeavour of invention that aims to liberate thought from the linguistic or texturalist paradigms otherwise dominating post-structuralist and difference philosophy (James 2013: 178). The works composing this project collectively address a persistent question: how can the materiality of the urban intertidal be seen and thought? Through an essentially performative approach, the project aims to renovate earlier epistemological approaches that ask how practices of seeing, speaking and writing produce, and sustain knowledge about the urban - a genealogy that can be traced through Foucault (1972), Certeau (1984), and Augé (1995). The project is an experiment that attempts to divest urban accounts of a long-exercised anthropocentricism. Instead, it pursues urban thought as a thing - a thing that faces the nonhuman to testify to a world no longer able to be seen and thought as constitutively "forus" (Meillassoux 2008: 54-5). The approach aspires to expand epistemic freedom via modes of thought-production that forego exclusively human perspectives and any economy of subjectivity that obstructs the world subsisting "for-itself" (Meillassoux 2008: 1). In other words, as Meillassoux has noted, in trying to think a "thing 'in-itself' it is necessary to think independently of its relation to me. ${ }^{3}$ (2008:1) This approach aims to make possible both new modes of discovery and to consolidate a form of critique not itself urban-focused. As such, it purposefully resists standard urban approaches and historicist frameworks. Firstly, it does this by intersecting photographic and philo-poetic practices, thereby eschewing disciplinary partitions. Secondly, it transposes the "radically new mode of thought" established by Laruelle (Gangle 2013: 6) from philosophy into urbanism.

Into this situation, what Laruelle offers is a radical mutation in thinking methodology, one that commits to a non-foundational understanding of thought that Galloway (2014) describes as a movement foreclosing the real as normatively given (48). Such thinking changes the nature of what can be thought and opens up how encounter can itself be encountered from a reorientated 'ground'. For Steven Shaviro (2014) this mutation amounts to a "nonphenomenology" or a "non-intuitive phenomenality" (130; emphasis in the orginal), which Laruelle claims makes manifest "radical immanence" (1999:141). In this sense, Laruelle effects a non-standard method to radically question basic assumptions and practices associated with analytic and conceptual thought (Galloway 2014: 47; Shaviro 2014: 132). Since materiality is not 'given' in the way that phenomenology describes, non-standard method doesn't adhere to naturalistic accounts of the world - with modes 
of perception say - instead Laruelle seeks an "experience of thought", which is to say an experience of immanence. Immanence for Laruelle offers a "manner of thinking" that is "always prior to any determination by transcendence" (Smith as cited in Mullarky \& Smith 2012: 26). To the extent that transcendence is given an explanatory place in and of the world, it is so as a limited condition of immanence itself. Familar references of thought such as logic and consistancy, themselves integral to transcendent thinking, are therfore avoided in Laruelle's non-standard method (Laruelle 2013b: 116) so that thought can abandon the illusory ground of philosophy in favour "of a real base - the only real base", that of the real itself (cited in James 2012:173). Critically thought is considered to neither rightly or wrongly represent reality; it instead avails an "ultra-reality" (James 2012:172) from thought as a material variant of what Laruelle calls the Real (Mullarky \& Smith 2012: 1-3). The Real, for Laruelle is immanence, and understood as that which is undivided, absolutely autonomous and, of itself, entirely indifferent and resistant to conceptual transcendence (James, 2012: 162). In non-philosophy's attempt to think this materiality, "thought [is] made stranger" (Mullarky \& Smith 2012: 37), yet despite its abstracted appearance, Laruelle's thinking is intended to be a practical theory, one whose performative orientation aims to do things to theory and perception specifically. Laruelle ventures to say that non-philosophy is "almost criminally performative" in the manner that this is the only way it can be demonstrated (cited in Ó Maoilearca 2015: 3). Fundamental to its design is how, non-standard method renders philosophical decision inoperable (Rodness 2015: 71) o open thought to a relation of alongside, a correlate of the Real, rather than of Being (Laruelle 1991:20). This study adapts such a posture in pursuit of a [non]urbanism, and in doing so, improvises a clearing for an expanded regime of (urban) thought - even if that thought assumes a difficult visage itself. To better situate non-standard method within urban inquiry, I have firstly sought strategies capable of disturbing phenomenal consciousness - in this case by way of photography. Secondly I have sought to transpose urban thinking as itself a material tendency or vector (Laruelle 2013b:100). Together these strategies stage a re-performance of the urban that is antithetical to personal accounts. Urbanism in this mode becomes a 'not-for profit' thing, no more privileged than a rock, or a dream in the scale of worldly things.

In this project becoming-immanent is privileged over programmatic practise. Such an approach is purposed to suspend prescriptive urban disciplinary norms and offer thought a non-foundation. Therefore, leveraged by an embodied encounter with the materiality of an urban intertidal space, Disquiet ventures through photography and philopoetics, to suspend personalised seeing and thought so it can rerecognise itself under re-scaled referents. To clarify, this experimental non-standard method thinks urban thing-ness by way of three strategies: firstly, a refusal of "natural perception" as exemplified by Merleau-Ponty (2002: 216; see also Gratton 2014; Sparrow 2014); secondly, thinking the event as if seen through a "world-without-us" (see Thacker 2011); and thirdly, by adopting an economy that "makes nothing happen" (see Blanchot 1989, 1993; Keats 1958). 


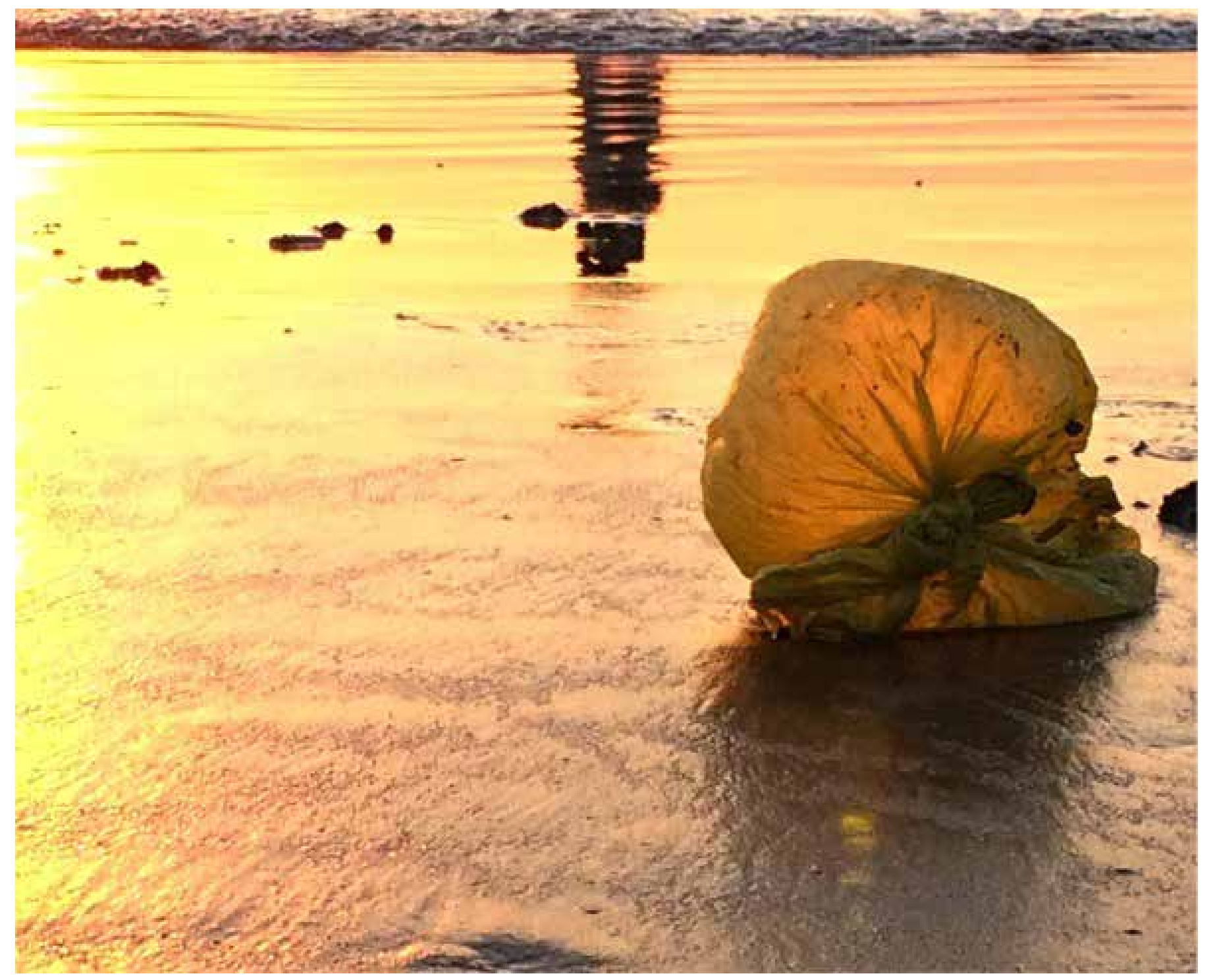

Fig 01

Untitled. Photo by author, 2014]

Disquiet in photographic register was shot using an iPhone 5 at dusk and for the purposes of this paper, cut from its original 9-minute length to 5 -minutes. The still images bring climate and urban material accumulation into play shadowed by human form. The photos were captured oblivious to explicate narrative, intentional decision, or intuition, and thereby refuse phenomenological intent. In line with Shaviro's depiction, they "exemplify a mode of thought that presents things without being about them-that is, without representing them or intending them as objects" (Shaviro 2014: 130). Taken rapidly with the non-philosophic function of stance not eye, they inscribe by drawing from an undivided presence contra to 'natural perception'. In this re-appropriation of Laruelle's nonstandard method, urban address is accordingly orientated away, not only from a phenomenological perceptual field, but also the predicates of program and social order, and away from social or political engagement per se. Consequently the tenure of the urban's conceptual authority and sufficiency is suspended (not destructed) to render the means and aesthetics of site reading (analysis) inoperable, yet is reopened to alternative modes of mapping. In orientating to 'sites', rather than being indexed to normatively evident phenomena, this project follows what Laruelle terms a universeorientation, which means attending (by way of an alongside relation) to the Real (or the One) that is in excess of the real as proximity found or given (Mullarky \& Smith 2012: 53). Laruelle’s Real, as radical immanence, always exceeds and escapes human definition, remaining indifferent (undifferentiated), (non)relational and reoriented to otherwise immediate ends or needs. In this project, a photographic stance is sought which attends to this undifferentiated existence of the world, an indifference to the distinction between the world and the body of the photographer (thinker), rather than testifying to or confirming directed intention, position, or decision. As Laruelle has identified in relation to photography:

The photographer does not throw himself into the World, he replaces himself firstly in his body as a stance, and renounces all corporeal or psychic intentionality. 'Stance'-this word means: to be rooted in oneself, to be held within one's own immanence, to be at one's station rather than in a position relative to the 'motif'. (Laruelle, 2011b: 12) 
Thus for Laruelle, the photographer is immediately plugged into a field of infinite materialities that remain beyond the complete grasp of any human (philosophical, semiological, analytical, artistic, etc.) cognition or technology (Laruelle 2011b: 53). Amplifying this stance, in this project the photography does not seek to be filled with representational content, but rather, remains open to a "presentation that has never been affected by and divided by representation" (Laruelle, 2011b: 45). In this mode, which amounts to 'letting things be', photography is something entirely objective in itself (Laruelle, 2011b: 94) and therefore resists vesting transcendent qualities in the urban.

Disquiet's radicalised mode of optics and edits borne from this mutated postural matrix privileges a seeing of seeing. It bears relation to seeing the surface of time, not as experience of an authoritatively imposed order tethered by its other, dis-order-what Michel de Certeau conceptually terms a "sieve-order" where the urban surface is taken as something capable of being "punched and torn open by ellipses drifts and leaks of meaning" (1984:108) - but rather, seeing a Laruellian "non-world fully rooted in the present" (Galloway 2012: 233). What non-standard method exercised through photographic performance brings to the question, how can urban intertidal materiality be seen and thought? is a disquieting, yet generative orientation that reconfigures the inscriptive gaze (what Laruelle calls a vision-force) to see the urban anew. At stake in Laruelle's abstracted photography is a new kind of "irreflective" thought akin to seeing without 'thinking' the blind-sight induced by logos. Similarly, the Juhu intertidal encounter 'grasps', via a poetic identification given (always insufficiently) by auto-portraiture, the manifold of intertidal things (see Laruelle 2011b, 2012a).

Using oblique, or tangential framings cut with top-down shots and mobilised through iPhoto in partial repetition, Disquiet's transposed non-standard method disorientates and pressures inscription of urban place away from habitual descriptions and categorical precincts through maintaining lapses of recognisable or knowable relations. Such a mutation of representation distresses interpretive constructs of normative place/ thing/human recognition, rendering the urban's relational cartographic navigation inert. Non-standard stance 'reads' urban discards and tidal material without measure or prejudice to enable encounter to enter a contract with 'whatever' material by accepting its fluency, swerve or stasis. Vision-force, or "immanence-of-vision" (Laruelle 2011b: 54) of the photograph makes everything it presents exist on a strictly "equal footing'. It amounts, "outside any ontological hierarchy" (Laruelle 2011b: 52), to a flattening out of thought without instigating a homogenisation of experience. As Alexander Galloway reads Laruelle's approach, the "nonstandard real is rooted in matter" (Galloway 2013:235), matter for Laruelle that always maintains a real equality.

In Disquiet I similarly circumvent an economy that distinguishes between waste and productive matter around which the urban political economy is typically coordinated. To this end the study aims to revive the dimensions of indifference as a critical position and democratising force in urban place. Laruelle's "indifference" is a non-philosophical apparatus that reconfigures subjects and object relations without reducing them to absolute alterity (2013: 107). Neither does it engender any explicit presence of the Other to provide "a structure of the perceptual field" (Delueze 1990: 307). As an alternative mode of relationality, the non-philosophical thinker, asserts Laruelle, is a force (of) thought, in which the "bracketed preposition expresses the immanence of thought and force as practise to affirm a (non) relation", a relation without correlation or reciprocity, a relation outside exchange. To such an end seeing and thought is not given effect in relation to, or about a perceived object or subject.
Urban thought as thing within (non-standard) method has value given it aspires to bring democracy (or 'flat' thinking) into urban discourse not as a theoretical democracy, but a "democracy of theory itself" (Ó Maoilearca 2015: 3). To this end Disquiet offers a partial, or preliminary aesthetic modelling of ontological and socio-political dilemmas within the urban by releasing the 'proper' boundaries of the human towards potentially contingent non-human utopias. Such a posture is neither subjective nor objective, neither for-us, nor for-itself, and instead aims to allow a "worldwithout-us" to flicker into view. The human is accordingly not annihilated or isolated from tidal processes taking place in encounter with any doctrines of lack or recovery, but opened to the future by way of troubling the surface of the present-a surface of shared primacy to which we are answerable.

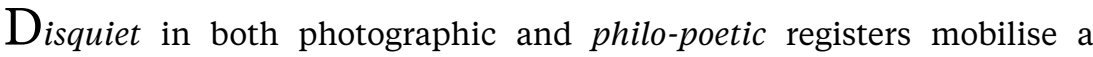
structure of effacement in their address of urban material things and thoughts that verges upon disappearance in affirming a "world-withoutus". The never-still intertidal space invokes an effect of the outside, a coexistent non-urban temporality (see Crary 2013 on urban time) that resites urban seeing beyond the lived present in a fractional revisioning of the Laruellian Real. This approach resonates with a rapid increase in the rate of measurable entropy across the planet in line with what Bernard Stiegler has reported as "a form of systemic mutation referred to as 'climate change"” (2015). As such it acknowledges the urgent need for changing perceptions of what is possible for urban seeing and thought. Extinction is itself a variant of effacement that troubles thinking about the urban. As Cary Wolfe recognises in the prospect of the demise of human inhabitation, "it comes from the future yet makes demands on the present, is natural, yet somehow never natural" (2015). On the other hand, effacement is deployed differently in this project. Rather than mobilising an eschatological "endthinking” resting on literal species extinction, the project pins its hopes on the possibility of deferred identity - not lost - on the "not-yet" as an inconspicuous and unstable synthetic space persisting in the present thingly body of the urban. To this end the materiality of effacement and the intertidal space of encounter converge within the components of the project to diffuse a rhetoric of extinction (See Brassier, 2007; Colebrook, 2014; Wolfe, 2015) and subvert a logic of crises - which more often than not means a logic more extremely applied to maintaining current socioeconomic practices.

nothing... will have taken place... but the place.. except.. perhaps... a constellation

Stéphane Mallarmé

Disquiet, in philo-poetic practice, is staged as sutured together lines of questions and statements in pursuit of a textual perform Laruelle calls "blind thought" or "irreflective thought" (Laruelle 2011b: 30-1). This fully-fledged abstraction of the actual Juhu Beach intertidal encounter presents no firm division between concrete and abstract, real and imaginary manifestation. The corrosive textual materiality aims to reterritorialise urban, earthbound thought with a non-personal vision-force-a force strange to the normative distinctions between concepts, humans and bodies. The poetics thus augment erosion of propriety, ontological positioning and determined place through an orientation, not to where, but from the multiple subject of the texts productive and destructive appeal (in fidelity with, or in other words a (non)relation alongside the Laruellian Real). The site of the subject, (including the reader), is troubled via a kinetics of pronoun to invoke 
an unnamed multiplicity with images of a folded, doublet 'you'-the generic 'urban human' and other material guises of the Real-alongside two registers of author: first person, and impersonal neuter. Operating indifferently to the various 'yous' that structure the text, the discursive impersonal neuter functions as a gate between overlapping subjects and objects. Dialogue is thus not coordinated in a bilateral relation, of 'me author' tethered to the other (site, tide, urban thing, reader...) in a reflexive or reciprocal contract, but by a unilateral relation to the neutral texture of the real whose boundaries can never be fully conceived. Hence, Disquiet in philo-poetic practise enlists Laruelle's indifference as a site of "descriptive passivity", a site where nothing happens as an analogous expression referred to by Blanchot (1989) as worklessness.

In summary, this truncated exploration attempts to locate fecundity in Laruelle's strange but lovely, rigorous rather than authoritative, nonphilosophical method as deployed alongside the urban as a means to map out thought as thing in a new site for spatial practice. It has begun to perform through photographic and textual practice how thought, as an immanent thing in itself, may appear for a [non]urbanism when the non is not a negation, but an amplification and mutation of thought (Mullarky \& Smith 2012: 15). It is too early to conclude with certainty the value of such a radical research practice, yet too late to discount non-philosophy's egalitarian contours that offer a mode of presence and reception in a realm of immanent, non-cognitive contact-an encounter with encounter potentially significant, for example, in unseating the transcendent primacy of the human gaze in urban 'interpretation' and urban discourse. 


\section{Endnotes}

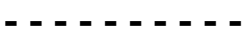

Speculative realis $m$ is neither a philosophical field, nor a unified movement. Nevertheless, it shares a set of concerns addressing what counts as 'experience' and the nature of the 'reality'. This work draws on the following thinkers who engage with, if not necessarily champion, speculative reality: Brassier 2007, Gratton 2014, Laruelle, Meillassoux 2008, Negarestani 2008, Shaviro 2014, Sparrow 2014, Trigg 2014.

$2 \quad$ Philo-poetics in this context builds on my own investigation of François Laruelle's "philo-fiction" as part of my PhD research into modes of encounter with the urban intertidal. For Laruelle (2013) "philo-fiction" is a reconfiguration of fiction that requires a nulling of philosophy's 'authority' over it as one way of radicalising what counts as reality and escaping fiction as belonging to the "order of the false" (228-230). In practice this involves the rigor or consistency of (fictional) invention, not convention, of philosophical possibilities alongside that of the real.

3 The bounds of this paperdo not permit a full account of this point that highlights correlationism in thought, and an impetus in materiality to seek the nonhuman orientations. See Grusin (2015) and Dolphijn, R., \& van der Tuin (2012). 


\section{References}

Augé, M. (1995). Non-places: Introduction to an anthropology of supermodernity (J. Howe, Trans.). London: Verso. Blanchot, M. (1989). The space of literature (A. Smock, Trans.). Lincoln and London: University of Nebraska Press. Blanchot, M. (1993). The infinite conversation (S. Hanson, Trans.). Minneapolis: University of Minnesota Press. Brassier, R. (2007). Nihil unbound: Enlightenment and extinction. Basingstoke, UK: Palgrave-Macmillan.

Certeau, M. d. (1988). The practice of everyday life, vol. 1 (S. Rendall, Trans.). Berkeley, California: University of California Press. Crary, J. (2013). 24/7. London: Verso.

Colebrook, C. (2014) Death of the posthuman: Essays on extinction, vol. 1. London, UK: Open Humanities Press.

De Landa, M. (1992) Inorganic life. In (J. Crary, S. Kwinter, Eds.), Incorporations, pp. 128-167. New York, NY: Zone Books. Deleuze, G. (1990). The logic of sense (M. Lester, Trans.). New York, NY: Columbia University Press.

Deleuze, G. (1998). Essays: Critical and clinical (D. W. Smith, M. A. Greco, Trans.). London, England \& New York, NY: Verso. Deleuze, G. (1992). The fold: Leibniz and the baroque (T. Conley, Trans.). Minneapolis, MN: University of Minnesota Press.

Deleuze, G. \& Guattari, F. (1987). A thousand plateaus: Capitalism and schizophrenia, volume 2 (B. Massumi, Trans.). Minneapolis, MN: University of Minnesota Press. Dolphijn, R., van der Tuin, I. (Eds), (2012). New materialism: Interviews and cartographies. Ann Arbor, MI: Open Humanties Press.

Foucault, M. (1970). The order of things: An archaeology of the human sciences (Tavistock Publications, Trans.). UK:Tavistock Publication/Routledge. Foucault, M. (1972). The archaeology of knowledge (A.M. Sheridan-Smith, Trans.). UK: Tavistock Publication/Routledge.

Galloway, A. (2012). Laruelle and Art. Continent 2.4, 230-236.

Gangle, R. (2013). François Laruelle's philosophies of difference: A critical introduction and guide. Edinburgh: Edinburgh University Press. Gratton, P. (2014). Speculative realism: Problems and prospects. London, England: Bloomsbury.

Grusin, R. (Ed). (2015). The Nonhuman turn. Minneapolis, MN: University of Minnesota Press.

James, I. (2012). The new french philosophy. Cambridge:Polity Press.

Keats, J., Garrod, H. W. (Ed.), (1958). The poetical works of John Keats. Oxford, England: Clarendon Press. 
Kolbert, E. (2014) The sixth extinction: An unnatural history. London, England: Bloosmbury

Kolozova, K. (2014). The cut of the real: Subjectivity in poststructuralist philosophy. New York, NY: Columbia University Press.

Land, N. (2011). Fanged noumena: Collected writings 1987-2007. New York, NY: Sequence Books.

Laruelle, F. (2008). Introduction aux sciences géneriques: Editions Petra, Paris.

Laruelle, F. (1999). A summary of non-philosophy (R Brassier, Trans.). Pli: Philosophies of Nature, 8, 138-148.

Laruelle, F. (2011a). Philosophies of difference (R. Gangle, Trans.). New York, NY: Continuum.

Laruelle, F. (2011b). The concept of non-photography (R. Mackay, Trans.). Falmouth: Urbanomic.

Laruelle, F. (2012a). Photo-fiction, a non-standard aesthetics (D. S. Burk, Trans.). Minneapolis, MN: Univocal.

Laruelle, F., Mackay, R. (Ed.), (2012b). From decision to heresy: Experiments in non-standard thought. Falmouth, UK: Urbanomic.

Laruelle, F. (2012c). What can non-philosophy do? In, The non-philosophy project (R Brassier, Trans.). New York: Telos Press.

Laruelle, F. (2013a). Philosophy and non-philosophy (T. Adkins, Trans.). Minneapolis, MN: Univocal.

Laruelle, F. (2013b). Principles of Non-Philosophy (N Rubczak, A Paul Smith, Trans.). London and New York, NY: Bloomsbury.

Lefebvre, H. (1991). The production of space (D. Nicholson-Smith, Trans.). Oxford, UK: Blackwell.

Mackay, R. \& François L. (2012). Introduction: Laruelle undivided. In F. Laruelle \& R. Mackay (Ed.), From decision to heresy: Experiments in non-standard thought, 1-32. Falmouth, UK: Urbanomic/Sequence Press.

Meillassoux, Q. (2008). After finitude: An essay on the necessity of contingency (R. Brassier, Trans.). London, England: Continuum.

Merleau-Ponty, M. (2002). Phenomenology of perception ( K. Paul, Trans.). London, England: Routledge.

Mullarky, J. (2006). Post-Continental philosophy: An outline. New York, NY: Continuum

Mullarky, J. \& Smith, A. P. [Eds.]. (2012d). Laruelle and non-philosophy. Edinburgh: Edinburgh University Press.

Ó Maoilearca, J. (2015). All thoughts are equal: Laruelle and nonhuman philosophy. Minneapolis, MN: University of Minnesota Press.

Rodness, R. (2015). On dismantling the master’s house. Francois Laruelle’s theory (in) practise. Chiasma \#1, 64-98.

Shaviro, S. (2014). The universe of things: On speculative realism. Minneapolis, MN: University of Minnesota Press.

Sparrow, T. (2014). The End of Phenomenology. Edinburgh: Edinburgh University Press.

Stiegler, B. (2015). Power, powerlessness, thinking and future. Retrieved from https://lareviewofbooks.org/essay/power-powerlessness-thinking-and-future

Thacker, E. (2011). In the dust of this planet. Winchester, England: Zero Books.

Trigg, D. (2014). The thing: A phenomenology of horror. Winchester, England: Zero Books.

Wolfe, C (2015). The poetics of extinction. Retrieved from https://www.youtube.com/watch?v=erpnVURnSQ4 